\title{
Biochemical and Histomorphological Impact of a Potential Chlorate Pesticide Agent on Tissues of the Giant African Land Snail (Archachatina marginata) as Indication of Toxicity
}

\author{
Onyegbula, K.C. ${ }^{1,2^{*}}$, Oluwaloye, T.G. ${ }^{2}$, Afolabi, A.S. ${ }^{2}$, Afolabi, T.E. ${ }^{3}$ \\ ${ }^{1}$ Department of Biomedical Laboratory Science, Faculty of Basic Medical Sciences, College of Medicine, University \\ of Ibadan,Nigeria \\ ${ }^{2}$ Department of Medical Laboratory Science, School of Public and Allied Health, Babcock University, Ilishan-Remo, \\ Nigeria \\ ${ }^{3}$ Genetics and Molecular Sciences Unit, Institute of Child Health, College of Medicine, University of Ibadan, Nigeria \\ "Corresponding Author \\ Department of Biomedical Laboratory Science, Faculty of Basic Medical Sciences \\ College of Medicine, University of Ibadan \\ Nigeria \\ E-mail: kennethchukwudionyegbula@yahoo.com \\ Tel: +2348034239571 \\ ORCID id: 0000-0001-8177-3440
}

\begin{tabular}{l|l|l|l|} 
Received:26 March 2021; & Revised:29 May 2021; & Accepted:06 September 2021
\end{tabular}

\section{Abstract}

Objective: Herbicides and pesticides are used in agricultural practice to mitigate activities of unwanted herbs and pests thereby boosting food production while exposing non-target organisms to their deleterious effects. This study investigated the biochemical and histological impact of a pesticide agent (potassium chlorate) on non-target giant African land snail (Archachatina marginata).

Methods: After laboratory acclimatization, thirty adult snails divided into six experimental groups of five snails each were exposed to 2 liters of distilled water (control), $1 \mathrm{mg} / \mathrm{L} \mathrm{KClO}_{3}, 2 \mathrm{mg} / \mathrm{L} \mathrm{KClO}$, $4 \mathrm{mg} / \mathrm{L}$ $\mathrm{KClO}_{3}, 8 \mathrm{mg} / \mathrm{L} \mathrm{KClO}_{3}$ and $10 \mathrm{mg} / \mathrm{L} \mathrm{KClO}_{3}$ respectively for 2 weeks after which edible foot region from each group were pooled together for analysis. Data was analyzed with descriptive statistics and results presented as standard deviation of mean. One sample T-Test was used to assess differences in mean values. Probability of $\leqslant 0.05$ was considered significant.

Results: Statistically significant differences were observed in mean values obtained for control and chlorate-exposed samples for alanine-aminotransferase $(\mathrm{P} \leqslant 0.05)$, alkaline-phosphatase $(\mathrm{P} \leqslant 0.05)$, gammaglutamyltransferase $(\mathrm{P} \leqslant 0.05)$, urea $(\mathrm{P} \leqslant 0.05)$, total-bilirubin $(\mathrm{P} \leqslant 0.05)$, conjugated-bilirubin $(\mathrm{P} \leqslant 0.05)$, total-protein $(\mathrm{P} \leqslant 0.05)$, globulin $(\mathrm{P} \leqslant 0.05)$, cholesterol $(\mathrm{P} \leqslant 0.05)$ and glucose $(\mathrm{P} \leqslant 0.05)$ but not for aspartate-aminotransferase $(\mathrm{P}>0.05)$, unconjugated-bilirubin $(\mathrm{P}>0.05)$ and albumin $(\mathrm{P}>0.05)$. Shrinkage and degeneration of mucous secreting unicellular glands and hyaline fibers, inflammatory cells and necrotic materials enclosed in vacuoles, vacuole formation within oblique muscle fibers, splitting and atrophy of oblique muscle fibers were observed in the chlorate-exposed samples. 
Conclusion: Biochemical and histological observations seen in this study are suggestive of liver and kidney dysfunction following exposure of the giant African land snail (Archachatina marginata) to the potassium chlorate pesticide agent. Caution should therefore be exercised in incorporating and adopting potassium chlorate as a proprietary pesticide agent.

Keywords: Histotoxicity, Pesticides, Oxidative enzymes, Liver dysfunction, Kidney dysfunction

\section{Introduction}

Nigeria is home to different species of land snails varying in size, color, adaptability and performance including Archachatina marginata, Achatina achatina, Achatina fulica, Limcolaria spp, [1- 4, 14]. Generally, the edible foot region of snails are reportedly rich in calcium, phosphorus, iron and all the amino acids required by man with low fat and saturated fatty acid content ${ }^{[5-14]}$. The giant African land snail (Archachatina marginata) is one of the largest known land snails widely distributed in the tropical and sub-tropical regions of the world [15]. It is one of the most important minor forest products in West Africa and Nigeria in particular where its production serves as cheap source of animal protein supply. The meat has a high protein content of about $83-93 \%{ }^{[16-17]}$, making it compare favorably with other conventional protein sources. In recent times, the activities of man including use of pesticides and other anthropogenic factors have led to a considerable decline in the wild snail population in Africa ${ }^{[18]}$.

Pesticides are toxic chemical substances or mixtures of substances or biological agents that are intentionally discharged into the environment to mitigate populations of insects, weeds, rodents, fungi or other harmful pests ${ }^{[19]}$. The use of pesticides in combination with irrigation, application of fertilizer to soil and mechanization helps to reduce damage to crops and maintain food production in order to feed Africa's growing population. Conversely, continuous use of pesticides may be problematic mainly due to their toxicity and environmental impact ${ }^{[20-21]}$. Over 98\% of sprayed insecticides and $95 \%$ of herbicides reach a destination other than their target species, because of the mode of application across entire agricultural fields ${ }^{[22]}$. Herbicides are the most widely used class of pesticides accounting for more than $60 \%$ of all pesticides applied in agriculture [23]. About 20 mechanisms of action, some sharing common target sites with mammalians have been elucidated [24]. Hence one of the main concerns about the use of herbicides and pesticides generally is their effects on non-target organisms. The chlorate anion $\left(\mathrm{ClO}_{3-}\right)$ and its salts (sodium chlorate, calcium chlorate, potassium chlorate and magnesium chlorate) are powerful oxidizers collectively known as chlorates having active ingredient status although, only sodium chlorate is currently registered for use as a herbicide ${ }^{[25-27]}$. The list of compounds for which toxic release inventory (TRI) reporting is required has never included a compound with "chlorate" in its name ${ }^{[28]}$. Considering the fact that picking of snails for consumption on farms that may have been sprayed with pesticides and other chemical products is a common practice in Southern Nigeria ${ }^{[29]}$, this study therefore seeks to evaluate histochemical and histological impact of non-proprietary potassium chlorate on the edible foot region of the giant African land snail (Archachatina marginata).

\section{Materials and Methods}

\section{Test Animals and Laboratory Acclimatization:}

Thirty giant African land snails (Archachatina marginata) purchased (within the month of May) from Omi-Adio market, Ibadan (Oyo state), Nigeria (Latitude: $7^{\circ}$ 23'38" and Longitude: $3^{\circ}$ 45'13"), within weight ranges of $43.31 \mathrm{~g}$ to $45.43 \mathrm{~g}$ were used for the experiments. The snails were allowed to acclimatize to laboratory conditions (temperature 25 $\pm 2{ }^{\circ} \mathrm{C}$, photoperiod $12 \mathrm{hL} / 12 \mathrm{hO}$, relative humidity $79 \pm 2 \%)$ in a plastic terrarium $(200 \mathrm{~cm} \mathrm{x} 80 \mathrm{~cm} \mathrm{x}$ $30 \mathrm{~cm}$ ) containing $2 \mathrm{~cm}$ layer of moist humus soil substrate for 7 days prior to commencement of potassium chlorate treatment ${ }^{[15]}$. The terrarium was covered with a wire mesh for proper ventilation and prevention of escape. The terrarium was wet daily with distilled water and snails were fed on 
fresh pawpaw leaves (carica papaya). Unconsumed food and fecal material were removed daily to prevent contamination.

Test Chemicals and Experimental Design:

Analar grade of potassium chlorate $\left(\mathrm{KClO}_{3}\right)$ as a representative of chlorate pesticide was used in this study. Solutions were prepared with distilled water. After the 7 days laboratory acclimatization, the snails were divided into 6 groups containing 5 animals each and maintained under existing laboratory conditions, however, snails in group 1 were exposed to soil and fresh pawpaw leaves wet with 2 liters of distilled water, snails in group 2 were exposed to soil and pawpaw leaves wet with 2 liters of $1 \mathrm{mg} / \mathrm{L}$ potassium chlorate solution, snails in group 3 were exposed to soil and pawpaw leaves wet with 2 liters of $2 \mathrm{mg} / \mathrm{L}$ potassium chlorate solution, snails in group 4 were exposed to soil and pawpaw leaves wet with 2 liters of $4 \mathrm{mg} / \mathrm{L}$ potassium chlorate solution, snails in group 5 were exposed to soil and pawpaw leaves wet with 2 liters of $8 \mathrm{mg} / \mathrm{L}$ potassium chlorate solution and snails in group 6 were exposed to soil and pawpaw leaves wet with 2 liters of $10 \mathrm{mg} / \mathrm{L}$ potassium chlorate solution on a daily basis for two weeks. Unconsumed food and fecal material were removed daily to prevent contamination. At the end of the exposure period, snails were weighed and starved for two days after which the foot region was harvested for subsequent analyses ${ }^{[15]}$.

\section{Biochemical Study:}

The harvested foot region from each experimental group were pooled together and homogenized in distilled water $(50 \mathrm{mg} / \mathrm{mL})$. The homogenates were centrifuged at $8000 \mathrm{rpm}$ for 1 minute at $5{ }^{\circ} \mathrm{C}$ in a refrigerated centrifuge. The deposits were discarded and the supernatant preserved at $-4{ }^{\circ} \mathrm{C}$ until used for (i) evaluation of liver and kidney function which includes: Aspartate aminotransferase (AST), Alanine aminotransferase (ALT), Alkaline phosphatase (ALP), Urea, Total bilirubin (TB), Conjugated bilirubin (CB) and Unconjugated bilirubin (UB), Total protein (TP), Albumin (ALB) and Globulin (GLOB), Cholesterol (CHOL) and Glucose (GLU) (ii) evaluation of antioxidant enzyme activity: Gamma glutamyltransferase (GGT).

\section{Histological Study:}

The harvested foot region from each experimental group were fixed in Bouin's fluid for 48 hours and thereafter subjected to several rinses in distilled water. They were then dehydrated by passing sequentially through $70 \%, 80 \%, 90 \%$ and $100 \%$ ethanol for 1 hour each and cleared in 2 changes of xylene for 1 hour each. This was followed by impregnation in 2 changes of molten paraffin wax for 1 hour each and embedding in molten paraffin wax using Tissue-Tek stainless steel embedding moulds. Blocked out samples were then sectioned at a thickness of $5 \mu \mathrm{m}$ on Histoline Laboratories MR 2258 rotary microtome and stained by the hematoxylin and eosin method. Slides from each group were observed under the microscope and photomicrographs were taken.

\section{Statistical Analysis:}

The results were computed statistically using SPSS version 23.0. Data are expressed as Mean \pm SD. One sample T-Test was used to check significance among means. Probability of $\leqslant 0.05$ was considered significant.

\section{Results}

Evaluation of Liver and Kidney Function:

To evaluate liver and kidney function, the levels of AST, ALT, ALP, UREA, TB, CB, UB, TP, ALB, GLOB, CHOL and GLU were determined in the extracts from the foot region of control and pesticide treated snails. It was generally observed that values for TP, ALB, AST, TB, CB, UB, UREA and GLU were higher in the pesticide treated than in the control snails; while values for GLOB, ALT, ALP and CHOL were lower in the pesticide treated than in the control snails (Table 1).

Evaluation of Antioxidant Enzyme Activity:

To evaluate antioxidant enzyme activity, GGT was determined in the extracts from the foot region of control and pesticide treated snails. Outcome of antioxidant enzyme activity show generally that pesticide treated snails had lower GGT value than control snails (Table 1). 
Table 1: Biochemical changes (as Mean \pm S.D) in the foot of the giant African land snail (Archachatina marginata) exposed to different concentrations of $\mathrm{KClO}_{3}$

\begin{tabular}{cccccccc}
\hline $\begin{array}{c}\text { Histo- } \\
\text { chemical } \\
\text { parameters }\end{array}$ & $\begin{array}{c}2 \text { liters of } \\
\text { distilled } \\
\text { water }\end{array}$ & $\begin{array}{c}2 \text { liters of } \\
1 \mathrm{mg} / \mathrm{L} \\
\mathrm{KClO}_{3}\end{array}$ & $\begin{array}{c}2 \text { liters of } \\
2 \mathrm{mg} / \mathrm{L} \\
\mathrm{KClO}_{3}\end{array}$ & $\begin{array}{c}2 \text { liters of } \\
\mathrm{mg} / \mathrm{L} \\
\mathrm{KClO}_{3}\end{array}$ & $\begin{array}{c}2 \text { liters of } \\
8 \mathrm{mg} / \mathrm{L} \\
\mathrm{KClO}_{3}\end{array}$ & $\begin{array}{c}2 \text { liters of } \\
10 \mathrm{mg} / \mathrm{L} \\
\mathrm{KClO}_{3}\end{array}$ & $\begin{array}{c}\text { P-value } \\
\text { TP }\end{array}$ \\
$0.67 \pm 0.03$ & $0.81 \pm 0.01$ & $0.28 \pm 0.02$ & $0.49 \pm 0.01$ & $0.19 \pm 0.01$ & $0.30 \pm 0.01$ & $0.01^{*}$ \\
ALB & $0.09 \pm 0.01$ & $0.51 \pm 0.02$ & $0.09 \pm 0.01$ & $0.09 \pm 0.01$ & $0.09 \pm 0.01$ & $0.21 \pm 0.01$ & 0.11 \\
GLOB & $0.59 \pm 0.01$ & $0.29 \pm 0.02$ & $0.19 \pm 0.01$ & $0.38 \pm 0.03$ & $0.09 \pm 0.01$ & $0.09 \pm 0.01$ & $0.03^{*}$ \\
ALT & $183.97 \pm 0.03$ & $133.99 \pm 0.04$ & $0.59 \pm 0.01$ & $120.03 \pm 0.06$ & $114.01 \pm 0.01$ & $120.00 \pm 0.01$ & $0.00^{*}$ \\
AST & $0.58 \pm 0.02$ & $11.01 \pm 0.01$ & $122.32 \pm 1.14$ & $0.09 \pm 0.01$ & $111.01 \pm 0.01$ & $117.00 \pm 0.01$ & 0.06 \\
ALP & $5103.02 \pm 0.03$ & $4304.01 \pm 0.01$ & $1328.02 \pm 0.03$ & $765.01 \pm 0.01$ & $538.01 \pm 0.01$ & $496.01 \pm 0.01$ & $0.05^{*}$ \\
GGT & $66.95 \pm 0.09$ & $59.03 \pm 0.03$ & $37.90 \pm 0.13$ & $13.01 \pm 0.01$ & $27.00 \pm 0.01$ & $43.00 \pm 0.01$ & $0.00^{*}$ \\
TB & $0.19 \pm 0.01$ & $0.29 \pm 0.01$ & $0.09 \pm 0.01$ & $0.21 \pm 0.01$ & $0.10 \pm 0.01$ & $0.50 \pm 0.01$ & $0.03^{*}$ \\
CB & $0.09 \pm 0.01$ & $0.19 \pm 0.02$ & $0.09 \pm 0.01$ & $0.21 \pm 0.01$ & $0.09 \pm 0.01$ & $0.31 \pm 0.01$ & $0.02^{*}$ \\
UB & $0.09 \pm 0.01$ & $0.09 \pm 0.01$ & $0.00 \pm 0.00$ & $0.00 \pm 0.00$ & $0.00 \pm 0.00$ & $0.21 \pm 0.01$ & 0.67 \\
CHOL & $53.91 \pm 0.03$ & $34.02 \pm 0.02$ & $14.01 \pm 0.01$ & $29.01 \pm 0.01$ & $31.00 \pm 0.01$ & $29.01 \pm 0.01$ & $0.00^{*}$ \\
UREA & $31.68 \pm 0.59$ & $23.01 \pm 0.02$ & $41.01 \pm 0.01$ & $34.01 \pm 0.01$ & $28.01 \pm 0.01$ & $7.00 \pm 0.01$ & $0.00^{*}$ \\
GLU & $20.98 \pm 0.03$ & $39.02 \pm 0.02$ & $34.01 \pm 0.01$ & $27.01 \pm 0.01$ & $40.01 \pm 0.01$ & $38.00 \pm 0.00$ & $0.00^{*}$ \\
\hline
\end{tabular}

Note: Concentration is in $\mathrm{mg} / \mathrm{dl}$.

Key: $\mathrm{TP}=$ Total protein, $\mathrm{ALB}=$ Albumin, $\mathrm{GLOB}=$ Globulin, $\mathrm{ALT}=$ Alanine-aminotransferase, $\mathrm{AST}=$ Aspartate-aminotransferase, ALP $=$ Alkaline- phosphatase, GGT $=$ Gamma-glutamyl transferase, $\mathrm{TB}=$ Total bilirubin, $\mathrm{CB}=$ conjugated bilirubin, $\mathrm{UB}=$ Unconjugated bilirubin, $\mathrm{CHOL}=$ Cholesterol, $\mathrm{UREA}=$ Urea, GLU $=$ Glucose.

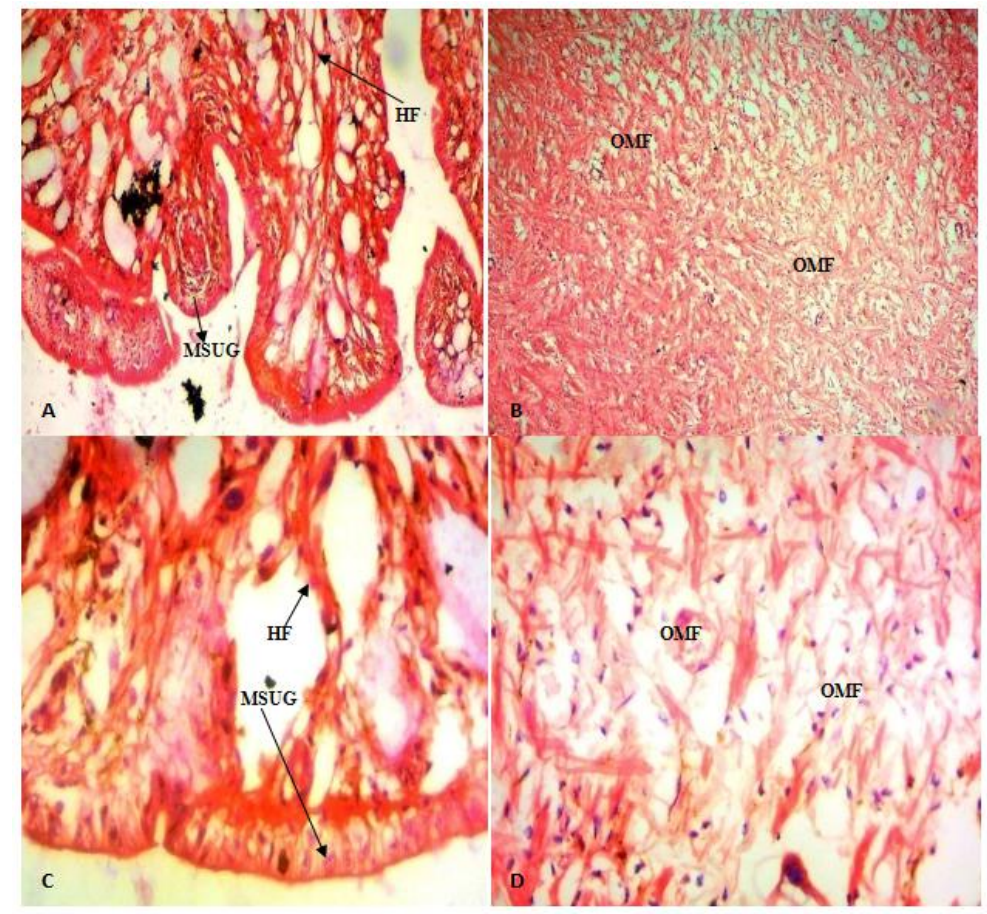

Figure 1: Histological sections of the foot of the giant African land snail (Archachatina marginata) in the control group after 2 weeks of exposure showing normal features: (A) hyaline fibers $\mathrm{HF}$ and mucous secreting unicellular glands MSUG x100; (B) oblique muscle fibers OMF x100; (C) hyaline fibers HF and mucous secreting unicellular glands MSUG x400; (D) oblique muscle fibers OMF x400 


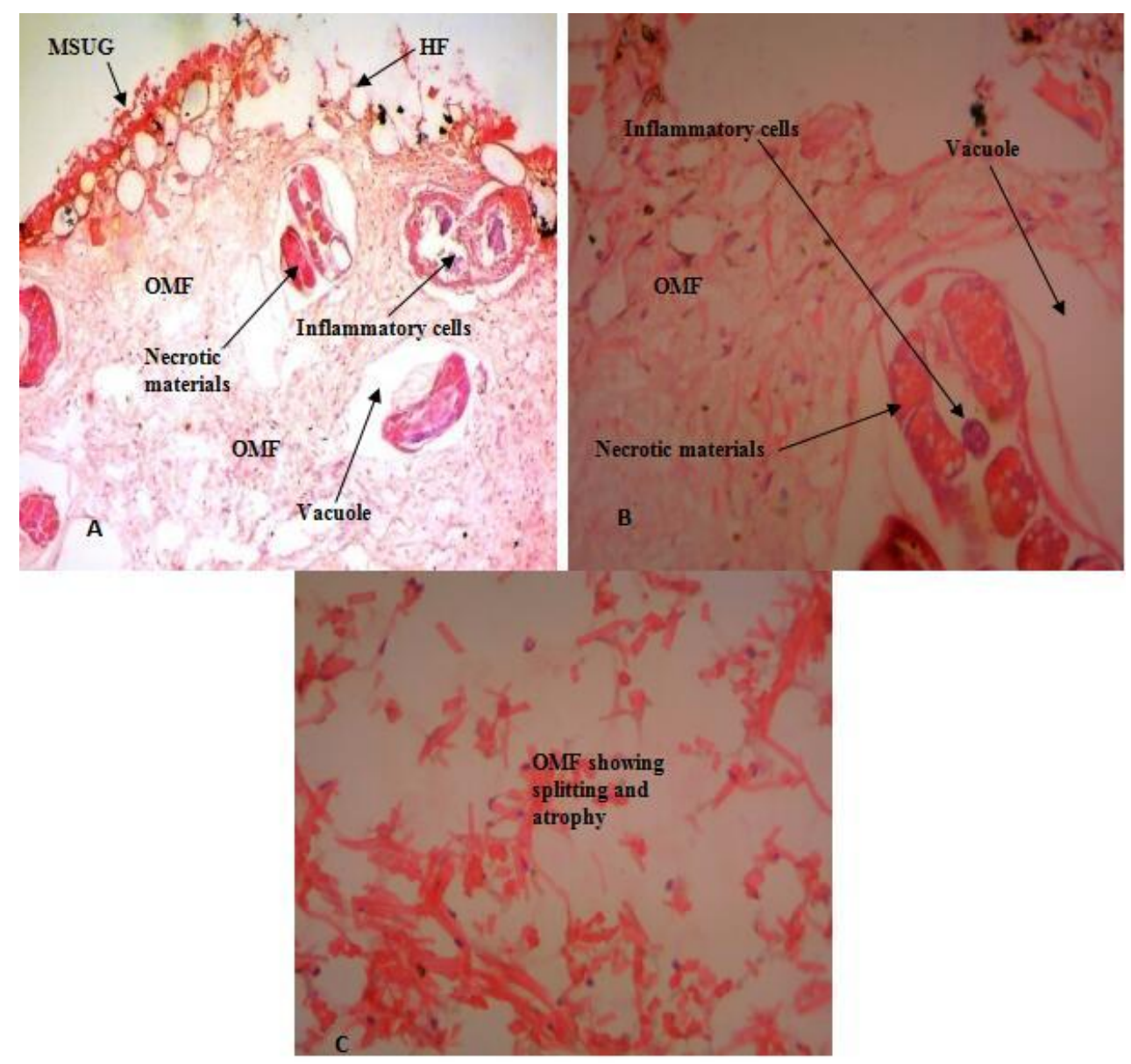

Figure 2: Histological sections of the foot of the giant African land snail (Archachatina marginata) in the pesticide treated groups after 2 weeks of exposure: (A) shrinkage and degeneration of mucous secreting unicellular glands MSUG and hyaline fibers HF, inflammatory cells enclosed in vacuoles with necrotic materials and vacuoles within oblique muscle fibers OMF x100; (B) vacuoles and necrotic areas within oblique muscle fibers OMF, inflammatory cells and necrotic materials enclosed in a vacuole within oblique muscle fibers OMF x400; (C) splitting and atrophy of oblique muscle fibers OMF x400

\section{Assessment of Histological Alterations in the Foot Region:}

To assess histological alterations in the foot region of snails exposed to control and experimental conditions, tissues were processed, sectioned, stained for general morphology and viewed microscopically. Representative control and pesticide treated sections of the foot region are shown in Figures 1 and 2 respectively.

\section{Discussion}

\section{Evaluation of AST:}

Extracts from the foot region of the giant African land snail (Archachatina marginata) exposed to control and pesticide-treatment conditions for two weeks were used to evaluate the activity of AST. Increased AST activity was observed in the pesticide-exposed snails. This increase was however not pesticide dose-dependent. As shown in Table 1, after two weeks of exposure, level of AST in the control snails was $0.58 \pm 0.02$ $\mathrm{mg} / \mathrm{dl}$. With the exception of snails exposed to $4 \mathrm{mg}$ of pesticide that had a value of $0.09 \pm 0.01 \mathrm{mg} / \mathrm{dl}$, all the other pesticide-exposed snails had elevated values with snails exposed to $2 \mathrm{mg}$ of pesticide being the highest at $122.32 \pm 1.14 \mathrm{mg} / \mathrm{dl}$ and snails exposed to $1 \mathrm{mg}$ of pesticide being the lowest at $11.01 \pm 0.01 \mathrm{mg} / \mathrm{dl}$. This agrees with previous reports in literature [30-31] which observed increased AST activity in land snails exposed to laboratory controlled pesticide induction and water snails harvested from a polluted lake respectively. Although statistical analysis of our result did not indicate significant difference $(\mathrm{P}>0.05)$, values 
obtained however suggests possibility of liver dysfunction.

\section{Evaluation of ALT:}

Extracts from the foot region of the giant African land snail (Archachatina marginata) exposed to control and potassium chlorate treatment conditions for two weeks were used to evaluate ALT activity. As shown in Table 1, after two weeks of exposure, the level of ALT in the control snails was $183.97 \pm 0.03 \mathrm{mg} / \mathrm{dl}$. However, all snails exposed to potassium chlorate exhibited none dosedependent reduced ALT level with snails exposed to $2 \mathrm{mg}$ of potassium chlorate being the lowest at $0.59 \pm 0.01 \mathrm{mg} / \mathrm{dl}$ and snails exposed to $1 \mathrm{mg}$ of potassium chlorate being the highest at $133.99 \pm 0.04$ $\mathrm{mg} / \mathrm{dl}$. This is contrary to reported increased ALT activity in land snails exposed to laboratory controlled pesticide induction and water snails harvested from a polluted lake respectively [30-31]. Statistical analysis of our result indicates significant difference in mean of ALT level $(\mathrm{P} \leq 0.05)$. This is further indicative of possible liver dysfunction.

\section{Evaluation of ALP:}

Extracts from the foot region of the giant African land snail (Archachatina marginata) exposed to control and pesticide treatment conditions for two weeks were used to evaluate ALP activity. A dose-dependent specific pattern of response to pesticide treatment was observed. As shown in Table 1, after two weeks of exposure, value of ALP in the control snails was $5103.02 \pm 0.03 \mathrm{mg} / \mathrm{dl}$. A progressive decline in the value of alkaline phosphatase as concentration of pesticide increased in the treated snails was observed with snails exposed to $1 \mathrm{mg}$ of pesticide being the highest at $4304.01 \pm 0.01 \mathrm{mg} / \mathrm{dl}$ and snails exposed to $10 \mathrm{mg}$ of pesticide being the lowest at $496.01 \pm 0.01 \mathrm{mg} / \mathrm{dl}$. This is at variance with previous reports ${ }^{[30-31]}$ which observed increased ALP activity in land snails exposed to laboratory controlled pesticide induction and water snails harvested from a polluted lake respectively. The difference in our values were statistically significant $(\mathrm{P} \leq 0.05)$ and suggestive of liver dysfunction.

\section{Evaluation of Urea:}

Extracts from the foot region of the giant African land snail (Archachatina marginata) exposed to control and pesticide treatment conditions for two weeks were used to evaluate the level of urea. As shown in Table 1, after two weeks of exposure, value of urea in control snails was $31.68 \pm 0.59 \mathrm{mg} / \mathrm{dl}$. However, in the pesticide exposed snails, the pattern of response to pesticide treatment was observably ambiguous. Further observations show that snails exposed to $1 \mathrm{mg}, 8$ $\mathrm{mg}$ and $10 \mathrm{mg}$ of pesticide exhibited reduced urea levels with those exposed to $10 \mathrm{mg}$ of pesticide being the lowest at $7.00 \pm 0.01 \mathrm{mg} / \mathrm{dl}$. On the other hand, snails exposed to $2 \mathrm{mg}$ and $4 \mathrm{mg}$ of pesticide exhibited elevated urea levels with those exposed to $2 \mathrm{mg}$ of pesticide being the highest at $41.01 \pm 0.01$ $\mathrm{mg} / \mathrm{dl}$. This is in contrast to a report ${ }^{[31]}$ which observed unequivocal increase in urea level in water snails harvested from a polluted lake. The differences in our result were however statistically significant $(\mathrm{P} \leq 0.05)$ and points to possible liver dysfunction.

\section{Evaluation of TB, CB and UB:}

Extracts from the foot region of the giant African land snail (Archachatina marginata) exposed to control and pesticide treatment conditions for two weeks were used to evaluate the level of total bilirubin, unconjugated and conjugated bilirubin. No specific pattern of response to pesticide exposure was observed for the three parameters. As shown in Table 1, after two weeks of exposure, value of total bilirubin in the control snails was $0.19 \pm 0.01 \mathrm{mg} / \mathrm{dl}$. In the pesticide-treated snails however, it was observed that snails exposed to $1 \mathrm{mg}$ and $10 \mathrm{mg}$ of pesticide had slightly elevated values at $0.29 \pm 0.01 \mathrm{mg} / \mathrm{dl}$ and $0.50 \pm 0.01 \mathrm{mg} / \mathrm{dl}$ respectively, while snails exposed to $2 \mathrm{mg}$ and $8 \mathrm{mg}$ of pesticide had slightly reduced values at $0.09 \pm 0.01$ and $0.10 \pm 0.01 \mathrm{mg} / \mathrm{dl}$ respectively. Levels of $\mathrm{CB}$ and $\mathrm{UB}$ in the control snails were both $0.09 \pm 0.01 \mathrm{mg} / \mathrm{dl}$. Similar to what was observed in the case of TB, snails exposed to pesticide treatments exhibited haphazard changes. This is in contrast to a report ${ }^{[31]}$ which observed a general increase in the level of these parameters in water snails harvested from a polluted lake. Differences in our result in the case of $\mathrm{TB}$ and $\mathrm{CB}$ respectively were statistically significant $(\mathrm{P} \leq 0.05 ; \mathrm{P} \leq 0.05)$ but not statistically significant in the case of UB $(\mathrm{P}>0.05)$. These results indicate possible liver dysfunction.

Evaluation of TP, Albumin and Globulin: 
Extracts from the foot region of the giant African land snail (Archachatina marginata) exposed to control and potassium chlorate treatment conditions for two weeks were used to evaluate the level of total protein, albumin and globulin. No specific pattern of response to pesticide treatment was observed. As shown in Table 1, after two weeks of exposure, level of total protein in the control snails was $0.67 \pm 0.03 \mathrm{mg} / \mathrm{dl}$. A slight elevation to $0.81 \pm 0.01 \mathrm{mg} / \mathrm{dl}$ was observed in snails exposed to $1 \mathrm{mg}$ of potassium chlorate. It was further observed that the level of total protein in snails exposed to $2 \mathrm{mg}, 4 \mathrm{mg}, 8 \mathrm{mg}$ and $10 \mathrm{mg}$ of potassium chlorate respectively were lower than in the control snails. Similarly, no specific pattern of response to potassium chlorate treatment was observed for albumin. While the level of albumin in the control snails was $0.09 \pm 0.01 \mathrm{mg} / \mathrm{dl}$, this was elevated to $0.51 \pm 0.02 \mathrm{mg} / \mathrm{dl}$ and $0.21 \pm 0.01 \mathrm{mg} / \mathrm{dl}$ in snails exposed to $1 \mathrm{mg}$ and $10 \mathrm{mg}$ of potassium chlorate respectively. Conversely, it was observed that the level of albumin in snails exposed to $2 \mathrm{mg}$, $4 \mathrm{mg}$ and $8 \mathrm{mg}$ of potassium chlorate remained unchanged from that of the control snails. A specific pattern of response to pesticide treatment was observed for globulin. While the level of globulin in control snails was $0.59 \pm 0.01 \mathrm{mg} / \mathrm{dl}$, a reduction in its level was observed in all the snails exposed to potassium chlorate with those exposed to $8 \mathrm{mg}$ and $10 \mathrm{mg}$ of potassium chlorate being the lowest at $0.09 \pm 0.01 \mathrm{mg} / \mathrm{dl}$ and snails exposed to 4 $\mathrm{mg}$ of potassium chlorate being the highest at $0.38 \pm 0.03 \mathrm{mg} / \mathrm{dl}$. In a report ${ }^{[31]}$, a general increase in the level of these parameters in water snails harvested from a polluted lake was observed. Another report ${ }^{[30]}$, also observed an increase in the level of TP in land snails exposed to laboratory controlled pesticide induction. In our result, while differences in total protein and globulin values respectively were statistically significant $(\mathrm{P} \leq 0.05$; $\mathrm{P} \leq 0.05)$, differences in the values obtained for albumin were not statistically significant $(\mathrm{P}>0.05)$. The results obtained are however indicative of possible liver and kidney dysfunction.

\section{Evaluation of Cholesterol:}

Extracts from the foot region of the giant African land snail (Archachatina marginata) exposed to control and pesticide treatment conditions for two weeks were used to evaluate the level of cholesterol. As shown in Table 1, after two weeks of exposure, value of cholesterol in control snails was $53.91 \pm 0.03 \mathrm{mg} / \mathrm{dl}$. However, in all the pesticide-exposed snails, a non-dose dependent specific pattern of response to pesticide treatment was observed. There was a general reduction in cholesterol level in the pesticide-exposed snails, with snails exposed to $2 \mathrm{mg}$ of pesticide being the lowest at $14.01 \pm 0.01 \mathrm{mg} / \mathrm{dl}$ and snails exposed to 1 $\mathrm{mg}$ of pesticide being the highest at $34.02 \pm 0.02$ $\mathrm{mg} / \mathrm{dl}$. This is at variance with a report ${ }^{[30]}$ which observed increased cholesterol level in land snails exposed to laboratory controlled pesticide induction. The differences observed in our result were statistically significant $(\mathrm{P} \leq 0.05)$ and indicates possible liver dysfunction.

\section{Evaluation of Glucose:}

Extracts from the foot region of the giant African land snail (Archachatina marginata) exposed to control and pesticide treatment conditions for two weeks were used to evaluate the level of glucose. As shown in Table 1, after two weeks of exposure, the level of glucose in the control snails was $20.98 \pm 0.03 \mathrm{mg} / \mathrm{dl}$. However, in the pesticide-exposed snails, a specific pattern of response to pesticide treatment was observed though not in a dose-dependent fashion. All the snails in the pesticide-exposed groups exhibited elevated glucose levels. It was further observed that snails exposed to $8 \mathrm{mg}$ of pesticide had the highest glucose level at $40.01 \pm 0.01 \mathrm{mg} / \mathrm{dl}$ and those exposed to $4 \mathrm{mg}$ of pesticide had the least at $27.01 \pm 0.01 \mathrm{mg} / \mathrm{dl}$. This is in agreement with a report ${ }^{[31]}$ which observed increased glucose level in water snails harvested from a polluted lake. The difference in our result was statistically significant $(\mathrm{P} \leq 0.05)$ and suggests possible liver dysfunction.

\section{Evaluation of GGT:}

Extracts from the foot region of the giant African land snail (Archachatina marginata) exposed to control and pesticide treatment conditions for two weeks were used to evaluate activity of GGT. A specific pattern of response to pesticide treatment was observed. As shown in Table 1, after two weeks of exposure, the level of GGT in the control snails was $66.95 \pm 0.09 \mathrm{mg} / \mathrm{dl}$. A general reduction in its level was observed in all pesticide-exposed snails, with the lowest being $13.01 \pm 0.01 \mathrm{mg} / \mathrm{dl}$ in the snails exposed to $4 \mathrm{mg}$ of 
pesticide. This is contrary to a report ${ }^{[31]}$ which observed a non-specific pattern of GGT activity in water snails harvested from a polluted lake. The differences observed in our result were statistically significant $(\mathrm{P} \leq 0.05)$ and indicates a possible liver dysfunction.

\section{Histological Alterations in the Foot Region:}

Figures 1 and 2 are histological sections of the foot region of the giant African land snail (Archachatina marginata) after two weeks of exposure to experimental conditions. While Figure 1 contains four representative photomicrographs (A-D) showing the normal features of the foot region in the control group, Figure 2 on the other hand contains three representative photomicrographs (A-C) showing the histological alterations observed in pesticide-exposed snails. Figure 1-A shows normal hyaline fibers and mucous secreting unicellular glands (mag. x100), while Figure 1-B shows normal oblique muscle fibers (mag. x100), furthermore Figure 1-C shows normal hyaline fibers and mucous secreting unicellular glands (mag. x400), and Figure 1-D shows normal oblique muscle fibers (mag. x400). In contrast, Figure 2-A shows shrinkage and degeneration of mucous secreting unicellular glands and hyaline fibers, inflammatory cells enclosed in vacuoles with necrotic materials and formation of vacuoles within oblique muscle fibers (mag. x100), while Figure 2-B shows vacuoles and necrotic areas within oblique muscle fibers, inflammatory cells and necrotic materials enclosed in a vacuole within oblique muscle fibers (mag. x400). Furthermore Figure 2-C shows splitting and atrophy of oblique muscle fibers (mag. x400). The observed histological derangements increased in severity in a dose-dependent pattern. This agrees with a report [31] which observed all the afore-mentioned histological derangements in water snails exposed to untreated waste from industrial, domestic and agricultural activities in a lake.

\section{Conclusions}

Going by the biochemical and histological observations made in this study, it is convenient to conclude that potassium-chlorate (a non-proprietary pesticide agent) produced deleterious toxic effects on non-target organisms such as the giant African land snail (Archachatina marginata) and this may be replicated over time in humans in the course of using such chemical formulations. In addition, consumption of such organisms should generate concern as this may predispose to serious public health hazards.

\section{Competing Interests}

The authors declare that there are no competing interests whatsoever.

\section{Author's Contributions}

Research concept and design, assembly, analysis and interpretation of raw data; statistical analysis and writing of article were done by $\mathrm{KCO}$. Laboratory experiments were done by $\mathrm{KCO}$, TGO and ASA. Critical revision and final approval of the article was done by KCO, TGO, ASA and TEA.

\section{Acknowledgements}

We would like to thank Professor J.C Ihongbe the head of the Department of Medical Laboratory Science, Babcock University, Ilishan Remo, Nigeria for provision of laboratory space and some disposables used in the conduct of this research. .

\section{References}

1 Amusan JA, Omidiji MO. Edible land snail: A technical guide to snail farming in the tropic. Verify Printer Limited, Ibadan, 1999; 5 - 50.

2 Ibom LA.Variations in reproductive and growth performance traits of white-skinned and black skinned African giant land snail hatchlings Archachatina marginata Swainson in Obubra, Nigeria. Ph.D Thesis. Department of Animal Science, University of Calabar, Nigeria, 2009.

3 Ejidike BN, Adewuyi CO. The giant African land snail (GALS) Archachatina marginata egg and adult sizes: Case study. Journal of Biodiversity, Bioprospecting and Development 2018; 5 (2): 1 - 4 DOI: 10.4172/2376-0214.1000171

4 Munonye JO, Moses P. Profitability analysis of snail farming in Owerri agricultural zone Imo state. Contributed paper presentation at the 
93rd Annual Conference of the Agricultural Economics Society, University of Warwick, England, 2019; 15-17.

5 Ajayi SS, Tewet OO, Moriarty C, Awesu MO. Observation of biological and nutritive value of the African giant snail (Archachatina marginata). African Journal of Ecology 1978; 16 (2): 85 - 95 DOI: $10.1111 / \mathrm{j} .1365-$ 2028.1978.tb00430.x

6 Adeyeye EI.Waste yield,proximate and mineral composition of three different types of land snails found in Nigeria. Int J Food Sci Nutr 1996; 47(2): 111-116 [PMID: 8833175 DOI: 10.3109/09637489609012572]

7 Ademosun AA,Omidiji MO.The Nutrient value of African giant land snail (Archachatina marginata). Journal of Animal Protection Research 1999; 8 (2): 876 - 877.

8 Omole AJ, Oluokun JA, Oredein AO, Adejuyigbe AP. Snail production potential for increasing animal protein intake in West Africa. In: Proceedings of the 26th annual conference of the Nigeria Society of Animal Production held in Ilorin, Nigeria between 21st and 25th of March, 1999; 393 - 401.

9 Ejidike BN. Snail rearing practices in Southern Nigerian. In: Proceedings of 27th Annual Conference of the NSAP held in Akure, 2002; $307-310$.

10 Akintomide IA. Tropical snail farming. Oak Ventures publishers Lagos, 2004; 5 - 6.

11 Anamayi SE, Anamayi RM, Okeke EN, Adams BA, Aderounmu EA. Marketing of edible land snail (Archachatina marginata) in Ibadan,In: Popoola L, Mfon P and Oni PI (eds). Proceedings of the 30th Annual Conference of FAN held in Kaduna, Kaduna State between 7th and 11th of November, 2005; 598 - 605.

12 Agbogidi OM, Okonta BC, Ezeana EL. Effects of two edible fruits on the growth performance of African giant land snail,(Archachatina marginata). Journal of Agricultural and Biological Science 2008; 3 (3): 26 - 29.

13 Miegoue E,Kuietche HM, Tendonkeng F, Lemoufouet J, Azemafac NP, Pamo T. Snail producton system in Fako Divison, South West Region - Cameroon. International Journal of Recent Innovations in Academic Research 2019; 3 (1): 1 - 14.
14 Adeyeye SAO,Bolaji OT, Abegunde TA, Adesina TO. Processing and utilization of snail meat in alleviating protein malnutrition in Africa: a review. Nutrition and Food Science 2020; Emerald Publishing Limited 0034-6659 DOI: 10.1108/NFS-08-2019-0261

15 Otitoloju AA,Ajikobi DO, Egonmwan RI. Histopathology and bioaccumulation of heavy metals $(\mathrm{Cu} \mathrm{\&} \mathrm{Pb})$ in the giant land snail, Archachatina marginata (Swainson). The Open Environmental Pollution and Toxicology Journal 2009; 1: 79 - 88.

16 Alikwe M,Okpeku K, Pek S,Ndukari S. Response of African giant land snail (Archachatina marginata) to graded levels of Asplenium barteri leaf meal supplement. Journal of Agriculture and Veterinary Science 2013; 6 (1): 32 - 35.

17 Dododawa Z, Adeyemo AI. Effects of two management systems on the growth performance of juvenile African giant land snails(Archachatina marginata). Journal of Research in Forestry, Wildlife and Environment 2019; 11 (1): 127 - 131.

18 Esak KO,Takerhash IS. Snails as pest and food. Malaysian Journal of Economic Agriculture 1992; 59: 359 - 367.

19 Mahmood I, Imadi SR, Shazadi K, Gul A, Hakeem KR. Effects of pesticides on environment in Plant, Soil and Microbes. Springer International Publishing Switzerland 2016; 253 - 269 DOI: 10.1007/978-3-319-27455-3 13

20 Eboua NW, Eric FE, Ernest K, Bodji NC, Brou C. Impact of the insecticide endosulfan on growth of the giant African land snail Achatina achatina (L). African Journal of Environmental Science and Technology 2010; 4 (10): 685 - 690.

21 Bruhl CA, Zaller JG. Biodiversity decline as a consequence of an inappropriate environmental risk assessment of pesticides. Frontiers in Environmental Science 2019; 7: 177 DOI: 10.3389/fenvs.2019.00177.

22 George TM. Sustaining the earth: Integrated approach. Thomson books/ Cole 2004; 211 216. 
23 Zimdahl RL. My view. Weed Science 2002; 50: 687 DOI: $\underline{10.1614 / 0043-1745920020050}$ [0687: MV] 2.0.CO; 2.

24 Shaner DL.Herbicide safety relative to common targets in plants and mammals. Pest Manag Sci 2004; 60(1): 17-24 [PMID: 14727737 DOI: $10.1002 /$ ps.782]

25 Usepa . Re-registration Eligibility Decision (RED) for Inorganic Chlorates. Office of Prevention, Pesticides and Toxic Substances EPA 738-R-06-014 July 2006. 2006a;

26 WHO.Safety Evaluation of Certain Food Additives and Contaminants. World Health Organization Food Additive Series 59. 2008; Geneva, Switzerland: WHO.

27 Usepa. Inorganic Chlorates Preliminary Work Plan. Registration Review: Initial Docket, Case Number 4049 March 2016. 2016c.

28 Usepa. Toxic Release Inventory (TRI)-Listed Chemicals. Available online at: https://www.epa.gov/toxics-release-inventorytri-program/tri-listed-chemicals. 2006b
29 Ejidike BN,Afolayan TA,Alokan JA. Influence of food and season on egg production of African Giant Land Snail (Archachatina marginata). In proceeding of the 27th Annual Conference Nigeria society for animal Production (NSAP), FUTA Nigeria, 2002; $309-311$.

30 Sharaf HM,Salama MA, Abd El-Atti MS. Biochemical and histological alterations in the digestive gland of the land snail Hellicella vestalis (Locard, 1882) exposed to Methiocarb and Chlorpyrifos in the laboratory. Journal of Cytology and Histology 2015; 6(3) DOI: 10. 4172/2157-7099.1000327

31 El-khayat $\mathrm{H}$, Abdel-Hamid $\mathrm{H}$, Gaber $\mathrm{H}$, Mahmood K, Elefel H. Snails and fish as pollution biomarkers in Lake Manzala and laboratory. Fisheries and Aquaculture Journal 2015; 6(4) DOI:10.4172/2150$\underline{3508.1000153}$ 